\title{
NOTES
}

\section{A JUDICIAL PROCESS STUDY OF THE REVLEW OF LICENSING DECISIONS OF THE PENNSYLVANIA LIQUOR CONTROL BOARD}

The majority's misconception of the power of the Board . . . demonstrate [s] the court's lack of competence in licensing matters and is so damaging to the orderly grant of licenses for the sale of liquor at retail that the legislature should immediately enact remedial legislation. ${ }^{1}$

Effective judicial review of administrative determinations depends on both legislative direction and judicial discretion. The review processes of state appellate courts, unlike their federal counterparts, have only infrequently been intensely scrutinized. In a small effort to fill this gap, this Note will analyze, as an example, the Pennsylvania judiciary's review of the Pennsylvania Liquor Control Board's (PLCB) licensing decisions. ${ }^{2}$ The following questions suggest the nature of the inquiry. Do the Pennsylvania courts properly defer to statutory allocations of discretionary power to the board? Have they developed consistent principles to govern similar substantive and scope of review problems? To what extent do the courts give effect to policy considerations basic to the Pennsylvania Liquor Code? Attention will be given to the way in which the courts use authorities. Observations will also be made concerning the effectiveness of present channels for review of board determinations, including the Pennsylvania Supreme Court's selection and disposition of cases under its discretionary allocatur jurisdiction. ${ }^{3}$ Although criticism of the substantive law is an inevitable by-product, the primary intent is to study judicial method.

\section{The Legislative Framework}

\section{A. The Pennsylvania Liquor Control Board}

The board is comprised of three members, appointed by the Governor and subject to the approval of two-thirds of the State senate. ${ }^{4}$ Of central

1 Willowbrook Country Club, Inc., Liquor License Case, 409 Pa. 370, 376, 187 A.2d 154, 157 (1962) (dissenting opinion).

2 The bulk of state-wide agencies come within the provisions of the Pennsylvania Administrative Agency Law. PA. Stat. ANN. tit. 71, \&1710.51 (Supp. 1964). The liquor control board, although subject to the Administrative Agency Law for most purposes, has its own scope-of-review provision. PA. Stat. Ann. tit. 47, §4-464 (1952).

3 Pa. Stat. Ann. tit. 17, §190 (Supp. 1964).

4 Pa. Stat. ANn. tit. 47, §2-201 (1952). 
significance in assessing the allocation of responsibility between the board and the courts is the board's competence and expertise. Although these highly subjective qualities defy evaluation in the absence of extensive working contact, the available extrinsic evidence suggests a strong legislative concern for securing a capable board. The salaries of the board's chairman (18,000 dollars) and its members (17,000 dollars) exceed those of virtually every other Pennsylvania commission or administrative agency, ${ }^{5}$ except the public utility commission. ${ }^{6}$ The PLCB's duties include administration of the state liquor stores and policing of outstanding licenses, ${ }^{7}$ whereas other Pennsylvania licensing boards engage exclusively in licensing activities at infrequent intervals and their members receive only small per diem allowances as compensation. ${ }^{8}$ Most other states do not compensate their liquor law administrators as liberally as does Pennsylvania.9

Significant comparisons can also be made with regard to the board's staff. Most Pennsylvania licensing authorities are severely understaffed and their employees frequently have only questionable qualifications. ${ }^{10}$ The board's enforcement functions are performed by approximately 150 officers, the second greatest number of any state. ${ }^{11}$ Although these employees do not participate directly in the issuance of licenses their services probably permit the board to devote more time to this function. More pertinent to the licensing process are the board's hearing examiners. In 1962 there were nine such examiners, ${ }^{12}$ each of whom was appointed by the Governor and must be "learned in the law." 13 Either the board on its own motion or the applicant may initiate a hearing before either the board or an examiner, ${ }^{14}$ with the ultimate grant or denial emanating from the board..$^{15}$ Hearings are safeguarded by the adjudicatory procedure of the Pennsylvania Administrative Agency Law. ${ }^{16}$

Finally, the legislature has attempted to avoid the conflict of interest problems that have haunted other Pennsylvania licensing boards, whose

5 See Pa. Stat. Ann. tit. 71, §773.2 (1962).

6 PA. Stat. ANN. tit. 66, §452(c) (1959) ( $\$ 20,000$ for chairman; $\$ 19,000$ for other members).

7 See PA. Stat. AnN. tit. 47, §2-207 (Supp. 1964).

${ }^{8}$ See Dean, The Opportunity To Be Heard in the Professional Licensing Process in Penusylvania, 67 Drck. L. REv. 31, 35 (1962).

9 See Cal. Gov't Cone $\$ 11560$ (Supp. 1964) ( $\$ 14,000$ to each member).

See also Joint Committee of the States To Study Alcoholic Beverage Laws, Alconolic Beverage Control 14, 79 (1960) [hereinafter cited as JoINT Consmittee STUDY].

10 See Dean, supra note 8 , at 36 .

11 JoInt CoMmitree STUDY 114 (1959 statistics). However, the staff had been halved during the period from 1949 to 1959 . Id. at 47 .

1295 The Peninsylvania Mandar 1961-1962, at 387 (Richey ed. 1962).

13 Pa. Stat. ANN. tit. 47, §4-402 (1952).

14 PA. Stat. ANN. tit. 47, §4-464 (1952).

15 Ibid.

16 PA. StAT. ANN. tit. 71, \$§ 1710.31-.36 (1962). See Club Oasis, Inc., Liquor License Case, $200 \mathrm{~Pa}$. Super. 439, 446, 188 A.2d 792, 796 (1963). See generally Schoenfeld, Administrative Discretion of the Pennsylvania Liquor Control Board in the Issuance of Licenses, 28 TEMrP. L.Q. 161, 181 (1954). 
members are selected from the regulated group. ${ }^{17}$ PLCB members or employees may not maintain any interest in an enterprise dealing in alcoholic beverages. ${ }^{18}$

\section{B. The Ground Rules of Liquor Licensing}

The legislature has attempted to control the abuses in consumption of alcohol ${ }^{19}$ by outlawing trade in liquor except as licensed by the state. ${ }^{20}$ The board's power to issue licenses for the retail sale of liquor ${ }^{21}$ extends to hotels, restaurants, and clubs, ${ }^{22}$ and is the exclusive source of authority for private retail sales. ${ }^{23}$ The Liquor Code imposes a quota of one retail liquor license for each fifteen hundred inhabitants of a municipality. ${ }^{24}$ Clubs, hotels, and airport restaurants are not counted in determining whether a quota will be exceeded, ${ }^{25}$ although once the quota is filled no new licenses may issue except to hotels or airport restaurants. ${ }^{28}$ The board's only other opportunity to exceed the quota limitations lies in its "power to increase the number of licenses in any . . . municipality which in the opinion of the board is located within a resort area." 27 However, many more licenses are actually outstanding than would appear to be authorized by the quota laws. ${ }^{28}$ This is due to the continuation of licenses previously granted under less stringent quota limitations. ${ }^{29}$

If the statutory requirements are met, hotel and restaurant liquor licenses must issue, but a club license may be issued or refused in the board's discretion. ${ }^{30}$ The board also may reject an otherwise proper application if the proposed location is within 300 feet of certain public and charitable institutions, ${ }^{31}$ or if the license would be detrimental to the wellbeing of the neighborhood within 500 feet. ${ }^{32}$

17 See Dean, supra note 8 , at $36-37$.

18 Pa. Stat. Ann. tit. 47, \$2-210 (1952).

19 PA. Stat. Ann. tit. 47, $\$ 1-104(a)$, (c) (1952).

20 E.g., Bierman Liquor License Case, 188 Pa. Super. 200, 145 A.2d 876 (1958); Tahiti Bar, Inc., Liquor License Case, $186 \mathrm{~Pa}$. Super. 214, 216, 142 A.2d 491, 492 (1958), aff'd, $395 \mathrm{~Pa} .355,150$ A.2d 112, appeal dismissed, 361 U.S. 85 (1959).

21 See Pa. Stat. Ann. tit. 47, §2-207(d) (1952).

22 See PA. Stat. Ann. tit. 47, §4 401 (1952).

23 See Pa. Stat. AnN. tit. 47, \$4-491(1) (1952).

24 PA. Stat. ANN. tit. 47, $\$ 4-461$ (a) (Supp. 1964). Before 1960 the quota was one license for each 1000 inhabitants. PA. STAT. ANN. tit. 47, §4-461 (1952). See generally Chind, Liquor UNder Control 83-84 (1960).

25 Pa. Stat. AnN. tit. 47, $\$ 4-461$ (Supp. 1964).

26 Ibid.

27 PA. Stat. ANn. tit. 47, §4-461 (b) (1952).

28 In 1958 there was approximately one liquor license for each 533 people although the statutory quota at the time was one license for each 1000 people. JoINT Commitres STUDY 99.

29 See, e.g., Carver Community Center Liquor License Case, 200 Pa. Super. 517, 189 A.2d 914 (1963).

30 Pa. Stat. Ann. tit. 47, $\S 4-404$ (Supp. 1964) ; cf. Pa. Stat. Ann. tit. 47, $\$ 4-432$ (a) (1952) for an identical distinction in the issuance of malt and brewed beverages retail licenses.

31 Pa. Stat. Ann. tit. 47, \$4-404 (Supp. 1964).

32 Ibid. 
An aggrieved party may appeal as of right to the quarter sessions court of the county in which the premises are located,"33 which court "shall hear the application de novo on questions of fact, administrative discretion and such other matters as are involved . . . ."34 A further appeal lies as of right to the superior court.35 An appeal to the Pennsylvania Supreme Court will follow only if "specially allowed by the Superior Court itself or by any one justice of the Supreme Court" 36_the device of "allocatur." However, this discretionary review power has not been used to fullest advantage: since the present Liquor Code was enacted in 1951, allocatur has been granted in only four cases involving the issuance of liquor licenses. ${ }^{37}$ The lack of contact by the supreme court belies the significant problems that the inferior courts have encountered in delineating judicial and administrative spheres of authority.

\section{Evolution of a Standard for Scope of Review}

\section{A. Early Standard of Review}

Before 1949 appeals from PLCB licensing determinations to the county quarter sessions courts were governed as to scope of review by the following provision: "The court shall hear the application de novo ...." 38 Moreover, the statute expressly precluded further appeal. ${ }^{39}$ In Pennsylvania this limitation leaves open only "narrow certiorari," a device restricting appellate review to questions of jurisdiction and procedural regularity. ${ }^{40}$ The general dissatisfaction with this scheme ${ }^{41}$ seems to have been warranted. Substantive determinations of law or fact by the lower tribunals were beyond the purview of the appellate courts. Despite the existence of a statewide agency administering a supposedly uniform liquor licensing policy, the quarter sessions courts of each county were independent and final authorities on the interpretation of the Liquor Code and on the policies which controlled licensing. ${ }^{42}$ Although some of these courts gave

33 Pa. Stat. AnN. tit. 47, $\$ 4-464$ (1952). In Allegheny County the appeal is to the county court. Ibid.

34 Ibid.

35 Ibid.

36 PA. Stat. ANN. tit. 17, §190 (Supp. 1964).

37 See Appeal of Speranza, $416 \mathrm{~Pa}$. 348, 206 A.2d 292 (1965); Willowbrook Country Club, Inc. Liquor License Case, 409 Pa. 370, 187 A.2d 154 (1962); Obradovich Liquor License Case, 386 Pa. 342, 126 A.2d 435 (1956); Sawdey Liquor License Case, 369 Pa. 19, 85 A.2d 28 (1951).

$38 \mathrm{~Pa}$. Laws 1937, act 370, § 404, at 1781 .

$39 \mathrm{~Pa}$. Laws 1933 , act $91, \S 7$, at 254 .

40 See Raby v. Board of Fin. \& Revenue, $405 \mathrm{~Pa} .495,176$ A.2d 661 (1962); Kaufman Constr. Co. v. Holcomb, 357 Pa. 514, 517-19, 55 A.2d 534, 535-36 (1947); Blair Liquor License Case, 158 Pa. Super. 365, 45 A.2d 421 (1946); Commonwealth v. Hilderbrand, 139 Pa. Super. 304, 11 A.2d 688 (1940); Note, 98 U.'PA. L. REv. 733 (1950).

41 See, e.g., Chinds, Making RePEAL WoRk 178-82 (1947); Byse, Opportinity To Be Heard in License Issisance, 101 U. PA. L. REv. 57, 85-86 (1952).

42 See McGettigan's Liquor License Case, 131 Pa. Super. 280, 286, 200 Atl. 213, 215 (1938). 
controlling weight to board decisions by reversing only if the board abused its discretion, others heard license applications completely anew, and totally disregarded the board's proceedings. ${ }^{43}$ Predictably, the lower courts' interpretations of the Liquor Code frequently were in conflict. ${ }^{44}$

Against this background, the superior court's desire to tighten the reins on lower court review of board decisions was understandable. In the leading case of Azarewicz Liquor License Case, ${ }^{45}$ the board under its statutory grant of discretion, had refused to license premises that were within three hundred feet of a church. ${ }^{46}$ On appeal the quarter sessions court overruled the board and ordered issuance of the license without finding specific or different facts. The superior court held that despite legislative authorization to the quarter sessions courts to hear the case de novo, they should not substitute their discretion for that of the PLCB on issues over which discretion is specifically granted the board. Since the superior court construed this discretionary authority to be exclusive, the court of quarter sessions would be permitted to reverse the board in these areas only upon a finding of new facts.

Because appellate court review before 1949 was confined to those issues cognizable on "narrow certiorari"-jurisdiction and the regularity of proceedings ${ }^{47}$-the superior court was left virtually powerless to correct even blatant errors of fact or law unless they could be squeezed into the "narrow certiorari" mold. The Azarezvicz majority, by framing the question in terms of the lower court's substitution of its discretion for that of the board, found an "irregularity in the proceedings." The superior court's reversal was probably impelled by the lower court's unreasoned reversal of a board decision that on its face was effectuating the statutory policy of restricting liquor licenses in the vicinity of churches. However, this decision is indicative of the general strain imposed by the courts on the "narrow certiorari" doctrine, as the Pennsylvania appellate courts struggled to assert control over the merits of controversies seemingly withheld from them by the legislature. ${ }^{48}$

Narrowly read, Azarewicz was confined to the modest holding that only substitution of discretion was reviewable. Thus, a lower court finding, on additional facts, that the board abused its discretion would in theory be a judgment on the merits immune from superior court consideration on "narrow certiorari" review, ${ }^{49}$ even in the face of a patently unreasonable decision below. Even more lamentably, if a quarter sessions court had reversed an apparently erroneous board decision without finding new

43 See Byse, supra note 41, at 86.

44 Ibid.

45163 Pa. Super. 459, 62 A.2d 78 (1948) (allocatur denied).

46 See PA. Stat. AnN. tit. 47, \$4-404 (Supp. 1964).

47 See authorities cited note 40 sipra.

48 See Note, 98 U. PA. L. Rev. 733, 736 (1950).

49 425-429, Inc., Liquor License Case, $179 \mathrm{~Pa}$. Super. 235, 116 A.2d 79 (1955) (allocatur denied). 
facts, the Azarewicz holding would require the superior court to nullify the quarter sessions' decision without examining the merits because of the "irregularity in the proceedings." Perhaps sensing the irrational ramifications of the majority's rule, a dissenter in Azarewicz reluctantly concluded that the quarter sessions court's exercise of discretion, even if only substitutionary, was an error of law and thus not reviewable on narrow certiorari. ${ }^{50}$ Although the case clearly presented important issues for the administration of liquor licensing and even broader issues regarding the scope of narrow certiorari review, the Pennsylvania Supreme Court nevertheless denied allocatur.

Since the opinion in Azarezericz was controlled by the superior court's necessity of working within the narrow certiorari restrictions upon their own appellate jurisdiction, it could not reflect the court's judgment on the proper scope of review of the board. The case thus shed little light on whether the superior court, on full review, would have allowed a quarter sessions court to exercise its own judgment on facts fully developed before it in a hearing de novo, ${ }^{51}$ or whether it would have confined quarter sessions' reversals to only those cases in which the board abused its discretion. The Azarewicz court did not have the power to promulgate either standard, and its decision seems inapposite to subsequent scope of review problems unencumbered by narrow certiorari limitations.

\section{B. Legislative Intervention}

The legislature, apparently sensitive to the developing problems, significantly amended the relevant statutes in the 1949 session, the first after the Azarewicz decision. ${ }^{52}$ The narrow certiorari doctrine, which had thwarted unification of the law through normal superior court review, was neutralized by specifically authorizing any party to the proceeding to appeal to the superior court. However, the legislature's alteration of the provision defining the quarter sessions' scope of review of the board was extremely ambiguous. Possibly wary of even Azarewicz's small incursion into the quarter sessions' freedom of decision, ${ }^{53}$ the legislature merely amplified the previous language, which had authorized a hearing de novo, by inserting the following italicized words:

The court shall hear the application de novo on questions of fact, administrative discretion and such other matters as are involved . . . . The court shall either sustain or over-rule the action of the board and either order or deny the issuance of a new license or the renewal or transfer of the license to the applicant. ${ }^{54}$

$50163 \mathrm{~Pa}$. Super. at 464-65, $62 \mathrm{~A} .2 \mathrm{~d}$ at 81.

51 Cf. Colligan Liquor License Case, 3 Bucks 34 (Ct. Quarter Sess. Bucks County, Pa., 1949).

52 The amendment brought the statute to its present form in PA. Star. ANN. tit. $47, \S 4-464$ (1952).

53 See 425-429, Inc., Liquor License Case, 179 Pa. Super. 235, 245-46, 116 A.2d

79,84 (1955) (dissenting opinion) (allocatur denied).

54 PA. Stat. Ann. tit. 47, \$4-464 (1952). 
The alternatives in construction are numerous. Does the de novo hearing "on questions of . . . administrative discretion" mean that the quarter sessions courts may freely substitute their discretion for the board's, ${ }^{55}$ thereby overturning Azarewicz's ruling that statutory grants of "discretion" to the liquor board were "exclusive"? Or is the board's exercise of discretion, if not abused, still final on questions that the Liquor Code expressly directs to the board's discretion, on the theory that such a legislative grant overrides the general scope of review provision? Does the amendment authorize the court to hear the question of administrative discretion de novo, but to decide on this record only the issue of whether the board abused its discretion? ${ }^{56}$

\section{Avoidance of the Amendment}

Regardless of the ultimate resolution of these issues of construction, the obvious starting point is an assessment of the impact of these crucial amendments in their setting as responses to the Azarezericz case. ${ }^{57}$ Nevertheless the appellate court development of a standard of review in liquor licensing cases was accomplished with misplaced reliance on Azarezricz and without discussion of the 1949 amendment. Although the quarter sessions courts were for the most part guilty of the same oversight, ${ }^{58}$ in the DiRocco License Case, ${ }^{59}$ decided shortly after the 1949 amendment, a quarter sessions court expressly exercised its independent judgment on whether the license should issue for premises within 300 feet of a school. ${ }^{60}$ "Without reference to any action the board may have taken," 61 the court reversed the board and issued the license. The superior court reversed on a collateral point without discussing the 1949 amendment or examining the lower court's assumption of authority to exercise unfettered "administrative discretion" in a de novo hearing. ${ }^{62}$

55 Byse, sttpra note 41, at 82; see, e.g., Duncan v. Mack, 59 Ariz. 36, 42, 122 P.2d 215, 218 (1942); Bell Appeal, 396 Pa. 592, 615, 646, 152 A.2d 731, 742-43, 757 (1959) (dissenting opinions).

56 This interpretation was ultimately accepted. See, e.g., Clinton Management, Inc., Liquor License Case, $188 \mathrm{~Pa}$. Super. 8, 12, 145 A.2d 873, 874-75 (1958); cf. De Mond v. Liquor Control Comm'n, 129 Conn. 642, 30 A.2d 547 (1943).

57 Cf. Statutory Construction Act, PA. STAT. Asn. tit. 46, §552(4) (1952). Compare Cohen Liquor License Case, 199 Pa. Super. 8, 12, 184 A.2d 387, 389 (1962) (allocatur denied) (inferring legislative approval of judicial rule from failing to alter it).

58 See Greene-Dreher Legion Home License, $69 \mathrm{~Pa}$. D. \& C. 425, 429-30 (Ct. Quarter Sess. Pike County 1949). But cf. Reigelsville Legion Home Liquor License, $86 \mathrm{~Pa}$. D. \& C. 309, 316 (Ct. Quarter Sess. Bucks County 1953).

$5969 \mathrm{~Pa}$. D. \& C. 370 (Ct. Quarter Sess. Chester County 1949), rev'd on other grounts, $167 \mathrm{~Pa}$. Super. 381, 74 A.2d 501 (1950).

60 Accord, In re Alessi, 39 Delaware 310 (Ct. Quarter Sess. Delaware County, Pa., 1952); In re Appeal of Subers, 40 Delaware 22 (Ct. Quarter Sess. Delaware County, Pa., 1952) (dictum). 1949).

61 DiRocco License, 69 Pa. D. \& C. 370, 371 (Ct. Quarter Sess. Chester County

62167 Pa. Super. 381, 74 A.2d 501 (1950). 
The next license issuance case to reach the superior court after the 1949 amendment was the Hotchkiss Liquor License Case. ${ }^{63}$ The board had refused a license because the applicant's premises were within 300 feet of a church. However, only four months later the board issued a license to the same applicant on substantially the same evidence. The superior court, affirming the lower court's denial of the license, held that the lower court had not merely substituted its discretion for the board's, but had found affirmatively that the board abused its discretion. Although the board merited reversal under either standard, the superior court, without expressly considering the alternative standards of review, seemed to give the quarter sessions courts a role far short of that conferred by a total de novo review of the board. In a misleading dictum which was to have considerable impact on future law, the court said:

Neither in the Azarewicz case nor in any other case have we failed to recognize the fundamental principle that administrative discretion is always subject to judicial review. The distinction between judicial review of administrative discretion and the substituting of judicial discretion for administrative discretion is by now well recognized .... ${ }^{64}$

The intimation that Azarezricz expressed a judgment that "abuse of discretion" is the proper standard of review for the quarter sessions courts was incorrect. It failed to recognize that Azarezericz was merely designating "substitution of discretion" as a procedural irregularity reviewable on narrow certiorari. Azarewicz did not purport to erect a standard of review for all cases in which the quarter sessions court conducts a full hearing. Not only did the Hotchkiss dictum fail to recognize the limited relevance of Azarewicz, it nowhere noticed or discussed the 1949 amendment's addition of "questions of administrative discretion" as matters considered de novo by the quarter sessions court.

Moreover, the court in Hotchkiss illustrated its "abuse-substitution" distinction erroneously drawn from Azarezicz with two lower court cases of questionable relevance. The first, Niedzinsky Post $624 \mathrm{Am}$. Legion License Case, ${ }^{65}$ was decided before the 1949 amendment and in dictum quoted language from Azarewicz itself out of context. In any event it is far from clear on the facts of Niedzinsky that the quarter sessions court really did limit itself to measuring the board's action by an abuse of discretion standard. ${ }^{66}$ The second lower court case mentioned in Hotchkiss

63169 Pa. Super. 506, 83 A.2d 398 (1951).

$64 I d$. at 511,83 A.2d at 400 .

$6566 \mathrm{~Pa}$. D. \& C. 618 (Ct. Quarter Sess. Lackawanna County 1949).

66 The board denied the license upon finding that the quota of nine licenses for the area was exceeded by thirty-two licenses, and that the premises were within 300 feet of a church. The quarter sessions court reversed, relying mainly on the presence of other licensed premises within 300 feet of the church, the absence of a complaint by the church (which is not required by statute for a denial of a license), and the general commercial character of the neighborhood. 
was Sylvan Seal Milk, Inc. v. Pennsylvania Milk Control Comm'n. ${ }^{67}$ The language in that opinion, quoted by Hotchkiss in defining the scope of review of liquor licensing determinations, referred to the review of milk control commission orders. The Sylvan Seal opinion expressly described the appeal to the courts under the applicable statute ${ }^{68}$ as "not a de novo proceeding," 60 thereby clearly distinguishing it from appeals under the Liquor Code.

The poorly supported and insufficiently analyzed Hotchkiss dictum obscured the importance of the statutory changes, and subsequent cases perpetuated this oversight. In 1953 the superior court in William E. Burrell I.B.P.O.E. of W. Liquor License Case ${ }^{70}$ cited for the first time the scope-of-review provision. However, the court simply assumed an "abuse of discretion" standard, citing Hotchkiss, ${ }^{71}$ without quoting or discussing the seemingly broader statutory standard for quarter sessions review. Since in Burrell the board was reversed for an abuse of discretion, differentiating between the alternative standards of review was again not crucial to the result. But in two cases soon to follow, Zermani Liquor License Case ${ }^{72}$ and Zeltner Liquor License Case, ${ }^{73}$ the court's failure to confront the issue of the proper scope of quarter sessions review may have affected the result. In both cases two or more qualified applicants were seeking the only license available under the applicable quota. In both cases the quarter sessions court, without finding materially different facts, ordered a license to be issued to an applicant not selected by the board, which would have been permissible only if the 1949 amendment had contemplated the unrestricted exercise of "administrative discretion" by the quarter sessions courts. However, the superior court, again ignoring the amendment, reversed the quarter sessions courts stating that they were to take evidence only to determine whether the board abused its discretion. ${ }^{74}$ Moreover, the Zermani opinion, in following the "abuse of discretion" standard, applied it to a factual situation not contemplated by Azarezericz. The court in the latter case had precluded the quarter sessions courts from substituting their discretion for the board's only where the Liquor Code expressly directed the board to exercise its own discretion on the issues in question. ${ }^{75}$ In Zermani, however, the "abuse of discretion" standard was extended to an application for a restaurant liquor license, which the board had no statutory discretion to deny. ${ }^{76}$

67 74 Pa. D. \& C. 289 (C.P. Philadelphia County 1951).

68 Pa. Stat. ANN. tit. 31, \&700j-906 (1958).

$6974 \mathrm{~Pa}$. D. \& C. at 297.

$70172 \mathrm{~Pa}$. Super. 346, 94 A.2d 110 (1953).

181 (1953).

71 Accord, Rizzo Liquor License Case, $174 \mathrm{~Pa}$. Super. 457, 460, 101 A.2d 180, $72173 \mathrm{~Pa}$. Super. 428, 98 A.2d 645 (1953).

$73174 \mathrm{~Pa}$. Super. 98, 100 A.2d 132 (1953). (1953).

74 See Zermani Liquor License Case, 173 Pa. Super. 428, 431, 98 A.2d 645, 647

${ }_{75}$ Azarewicz Liquor License Case, $163 \mathrm{~Pa}$. Super. 459, 62 A.2d 78 (1948); see text accompanying notes $45-46$ supra.

78 See Pa. Stat. ANN. tit. 47, §4-404 (Supp. 1964). 
The issue of the appropriate quarter sessions scope of review was clearly argued to the superior court for the first time in Booker Hotel Corp. Liquor License Case, ${ }^{77}$ where the appellant urged that the lower court "erred in not exercising its own independent discretion following the hearing de novo." 78 But the superior court reaffirmed the "abuse of discretion" standard, ${ }^{79}$ supporting this conclusion only by citation of its own recent cases with no mention of the 1949 amendment. The Pennsylvania Supreme Court denied allocatur. A glint of the superior court's awareness of the statutory amendment is suggested by its citation form. Although the most recent cases supporting its position were cited directly, the Azarewicz case, decided before the amendment, was introduced as collateral authority..$^{80}$ This change in citation signals may have been intended to reveal the court's conclusion that the 1949 amendment did not empower the quarter sessions courts to exercise "administrative discretion," but it certainly was not calculated to attract much attention.

The superior court also missed another opportunity in Booker Hotel to rationalize its holding. The license applicant, contending that the quarter sessions court should freely exercise its independent discretion, analogized to the Pennsylvania Motor Vehicle Code under which the lower court is given complete discretion to rule de novo in license suspension cases, regardless of the evidence taken before the secretary of revenue. ${ }^{81}$ The relevant statutory language charges the lower court "to take testimony and examine into the facts of the case, and to determine whether the petitioner is subject to suspension of operator's license . . . ." 82 Although the differences between this statute and the de novo review provision of the Liquor Code are not self-evident, the court reached a contrary result without express analysis. It merely said of the Motor Vehicle Code case cited by appellant that "the decision is plainly inapplicable." 83 Perhaps the court was swayed by the difference in statutory language between a lower court "determining" the issue anew under the Motor Vehicle Code and its "hearing" of the issue de novo under the Liquor Code. Possibly the court felt that in motor vehicle license suspension cases the lower courts should have complete freedom of decision to compensate for the

77175 Pa. Super. 89, 103 A.2d 486 (1954) (allocatur denied).

78 Id. at 91,103 A.2d at 487.

79 Accord, Bierman Liquor License Case, 188 Pa. Super. 200, 145 A.2d 876 (1958); Haase Liquor License Case, $184 \mathrm{~Pa}$. Super. 356, 134 A.2d 682 (1957); De Angelis Liquor License Case, $183 \mathrm{~Pa}$. Super. 388, 133 A.2d 266 (1957); Rzasa's Liquor License Case, $179 \mathrm{~Pa}$. Super. 30, 115 A.2d 797 (1955) ; Her-Bell, Inc., Liquor License Case, $176 \mathrm{~Pa}$. Super. 206, 107 A.2d 572 (1954).

$80175 \mathrm{~Pa}$. Super. at $93,103 \mathrm{~A} .2 \mathrm{~d}$ at 488 .

81 Ibid. See also Appeal of First Presbyterian Church, 39 Washington 150 (Ct. Quarter Sess. Washington County, Pa., 1959).

82 PA. Stat. ANn. tit. 75, $\$ 620$ (Supp. 1964). The language is still interpreted to give the lower court complete discretion de novo. Rabin Motor Vehicle Operator License Case, $196 \mathrm{~Pa}$. Super. 555, 176 A.2d 460 (1961). See also Commonwealth v. Wagner, $364 \mathrm{~Pa}$. 566, 568, 73 A.2d 676, 677 (1950).

$83175 \mathrm{~Pa}$. Super. at 93, 103 A.2d at 488. 
informality of administrative hearing procedures. The usefulness of the Booker Hotel opinion would have been greatly enhanced if the court had explained its basis for distinction.

\section{Division in the Superior Court Over Proper Scope of Reviezer}

Not until 1955, in the 425-429, Inc. Liquor License Case, ${ }^{84}$ was the 1949 amendment's significance openly discussed in an appellate court opinion. Although the majority reversed the quarter sessions court for substituting its discretion for that of the board, Judge Ervin's dissent traced the origin of the majority's principle to Azarewicz and concluded that in the 1949 amendment "the legislature intended the [quarter sessions] court on appeal to have administrative discretion to determine whether or not the application should be granted." 85 Judge Ervin appropriately would have limited the superior court's function to effectuating the legislative intent, without regard to personal views on the merits of the competing policy arguments. Despite this overt split in the superior court and the clear exposition of the grounds of difference in Judge Ervin's dissent, ${ }^{86}$ the Pennsylvania Supreme Court again denied allocatur.

Judge Ervin's views on the proper scope of quarter sessions review reappeared three years later in Judge Gunther's dissent in Kreiser Liquor License Case. ${ }^{87}$ The majority held that the quarter sessions court, in reversing the board's determination that the area in question was not a "resort," 88 had overstepped the bounds of an "abuse of discretion" review. Judge Gunther, however, would have upheld the lower court. Apparently rejecting the "abuse of discretion" standard, he stated the question on appeal to be "whether there is sufficient evidence in the [quarter sessions] record to show that Franklin Township . . . is located in a resort area . . . ." 89 In Cialella Liquor License Case, ${ }^{90}$ the court again applied an "abuse of discretion" standard, but a concurring opinion implored the supreme court to examine on allocatur the impact of the 1949 amendment on the scope of quarter sessions review, although the plea went unheeded.

\section{E. The Superior Court's Shift in the Standard of Review and Action by the Supreme Court}

In the year following Cialella, the standard of review expressed by Judge Gunther dissenting in Kreiser became without explanation the

$84179 \mathrm{~Pa}$. Super. 235, 116 A.2d 79 (1955) (allocatur denied).

85 Id. at 245,116 A.2d at 84 .

86 Judge Ervin's concurrence without opinion in Her-Bell, Inc., Liquor License Case, $176 \mathrm{~Pa}$. Super. 206, 107 A.2d 572 (1954), was subsequently explained to be on the ground that he differed with the majority's formulation of the scope-of-review standard. See 425-429, Inc., Liquor License Case, 179 Pa. Super. 239, 245, 116 A.2d 79, 84 (1955) (dissenting opinion).

$\$ 7188 \mathrm{~Pa}$. Super. 206, 209, 145 A.2d 880, 881 (1958).

88 See generally PA. StAT. ANN. tit. 47, \$ 4-461(b) (1952); notes 176-180 infra and accompanying text.

$89188 \mathrm{~Pa}$. Super. at 210, $145 \mathrm{~A} .2 \mathrm{~d}$ at 881 . (Emphasis added.)

$90191 \mathrm{~Pa}$. Super. 526, 531, 159 A.2d 64, 67 (1960) (allocatur denied). 
majority's standard in William Penn Sportsmen's Ass'n Liquor License Case.91 The quarter sessions court had reversed the board, which had denied a resort club license on the apparently plausible ground of lack of need. ${ }^{92}$ The superior court agreed with the trial court "that the applicant has produced sufficient testimony to show there is a necessity for the facilities ...., ${ }^{93}$ and affirmed, without alluding to an abuse of discretion by the board. When the superior court accorded identical treatment to the board's denial of a resort club license in Willowbrook Country Club, Inc. Liquor License Case, ${ }^{94}$ the Pennsylvania Supreme Court finally granted allocatur.

The choice to review Willowbrook on allocatur was a good one. Not only did the case present troublesome problems of statutory interpretation, ${ }^{95}$ but it also re-emphasized the need for a definitive exploration of the appropriate scope-of-review standard for the quarter sessions courts. Unfortunately, the supreme court did not address itself directly to the scope-of-review issues, but treated them almost in passing:

We thoroughly agree with the conclusion of [the superior court] . . . that the proof in the record clearly sustains the conclusion, that the proposed licensed premises are in a "resort area" as contemplated by the legislature . . . and that the Board abused its discretion in concluding otherwise. ${ }^{96}$

In fact the superior court had never accused the board of an abuse of discretion, and, on the issues actually raised by the case, the board was probably not responsible for more than an error of judgment. ${ }^{97}$ Nonetheless, in one sentence the supreme court mingled both standards of review without suggesting a distinction. The court then resolved the second substantive issue in the case, the "need" for the license, by noting merely that "the testimony cleary manifests a substantial need ... . "98 The phrase again muddles the distinction between the quarter sessions courts exercising independent judgment on the testimony developed before them and their determining whether the board abused its statutory discretion. Mr. Justice Cohen dissented, noting that "the Liquor Code' provided for a system of complete regulation and assigned to the courts only appellate review." 99 Although he, too, ignored the statutory language governing scope of review, his position that a major objective of the present Liquor Code was to remove the courts' licensing functions suggests his awareness

91196 Pa. Super. 519, 175 A.2d 908 (1961).

92 See note 179 infra and accompanying text.

$93196 \mathrm{~Pa}$. Super. at 523, 175 A.2d at 910 (Emphasis added.) ; accord, Mannitto Haven Liquor License Case, $196 \mathrm{~Pa}$. Super. 524, 175 A.2d 911 (1961).

94 $198 \mathrm{~Pa}$. Super. 242, 181 A.2d 698, aff'd, $409 \mathrm{~Pa}, 370,187$ A.2d 154 (1962).

95 See notes 199-209 infra and accompanying text.

$96409 \mathrm{~Pa}$. at 373, $187 \mathrm{A.2d}$ at 155 . (Emphasis added.)

97 See notes 199-209 infra and accompanying text.

$98409 \mathrm{~Pa}$. at 375, $187 \mathrm{~A} .2 \mathrm{~d}$ at 146. (Emphasis added.)

99 Ibid. 
of the standard of review issues and his inclination toward an abuse of discretion standard.

In light of the small number of cases that the supreme court hears on allocatur, strategic selection and thoughtful disposition are essential. If anything, the court's allocatur opinions should reflect even more exhaustive analysis and more precise articulation than opinions in its mandatory jurisdiction cases, which necessarily include many relatively routine matters. ${ }^{100}$ The superficial treatment of the scope-of-review issues in Willowbrook does not seem satisfactorily to discharge the court's obligation to use its discretionary jurisdiction to settle the law in areas normally not before it.

\section{F. Post-Willowbrook Standards of Review}

Two cases decided shortly after Willowbrook demonstrated that the confusion concerning proper scope of quarter sessions review was not dispelled by the supreme court. One strongly suggests that the quarter sessions court's discretion could supplant that of the board in determining whether the applicant's premises were in a "resort" area, ${ }^{101}$ while the other, not a resort-area case, proclaimed that "abuse of discretion" is the standard for reviewing board determinations that the license would be detrimental to the neighborhood. ${ }^{102}$ Several months later in Chub Oasis Liquor License Case, ${ }^{103}$ also not a resort-area case, the superior court, describing the 1949 amendment for the first time in a majority opinion, emphatically stated that "abuse of discretion" is the only question properly before the quarter sessions courts. In support of this statement, the court cited ten cases, including Azarewicz, ${ }^{104}$ although curiously neglecting to cite the Willowbrook case, the only Pennsylvania Supreme Court pronouncement in the area in recent years. Moreover, none of the cases cited were from the line of resort-club cases, culminating in Willowbrook, that had drifted toward the unrestricted exercise of discretion by the quarter sessions courts. The specter of dual lines of authority interpreting the same statutory provision was soon vanquished, however, in Andes Grove Rod \& Gun Chib Liquor License Case. ${ }^{105}$ The court deliberately reinstated the original rule that the quarter sessions court, even in resort-club cases, could reverse the liquor board only when the court's specific findings demonstrated that

100 For example, the supreme court's mandatory jurisdiction includes all civil suits in which the amount in controversy exceeds $\$ 10,000$. Compare PA. STAT. ANN. tit. 17, \& 41 (1962), with PA. Stat. ANn. tit. 17, \$\$181, 184 (Supp. 1964).

101 Wildwood Golf Club Liquor License Case, 199 Pa. Super. 353, 359, 185 A.2d 649, 653 (1962) (allocatur denied).

102 Gismondi Liquor License Case, 199 Pa. Super. 619, 186 A.2d 448 (1962); see Koppenhaver Liquor License Case, 200 Pa. Super. 214, 188 A.2d 847 (1963).

103 Id. at 439,188 A.2d 792.

104 Id. at 445 n.3, 188 A.2d at 795 n.3.

105201 Pa. Super. 21, 190 A.2d 355 (1963). 
the board abused its discretion. Subsequent cases in the several areas of board discretion have for the most part adhered to this doctrine..$^{106}$

\section{G. Possible Explanations of and Alternatives to the Courts' Treatment of the Scope-of-Review Standard}

For better or for worse, "abuse of discretion" has become the established standard for judicial review of liquor license determinations, even though this interpretation of the statute does not seem to have been deliberately chosen by the judiciary. Rather, it seems more likely that the appellate courts were precluded tactically from reversing themselves after repeatedly overlooking a statutory amendment that seemed to expand the discretion exercisable by the quarter sessions courts.

The courts' questionable use of authorities in reaching this result could have been buttressed by resort to the admittedly strong policies standing in opposition to complete de novo review of PLCB licensing determinations. Bestowing such broad discretion upon the lower courts would eliminate any benefits accruing from the fact that the board's full-time administration of the liquor business in Pennsylvania has equipped it with the expertise to evaluate applicants and to decide on the proper distribution of liquor licenses. ${ }^{107}$ But even apart from the quality of adjudication, it is desirable from the standpoints of evenhandedness and coordination to have a unitary source of policy for licensing decisions. ${ }^{108}$ Immersing the local judiciary in the licensing process, with its political overtones, subjects it to unnecessary pressure and controversy. ${ }^{109}$ An indication of the courts' inclination to reward license applicants appears in the often cited statistic that as of

106 See Koehler's Bar, Inc., Liquor License Case, 204 Pa. Super. 25, 201 A.2d 306 (1964); Jack's Delicatessen, Inc., Liquor License Case, 202 Pa. Super. 481, 198 A.2d 604 (1964); Seventeenth Ward United Veterans Ass'n Liquor License Case, $202 \mathrm{~Pa}$. Super. 196, 195 A.2d 893 (1963) ; Teti Liquor License Case, $201 \mathrm{~Pa}$. Super. 87, 191 A.2d 683 (1963); Solomon Liquor License Case, 201 Pa. Super. 82, 191 A.2d 681 (1963); Riviera Country Club Liquor License Case, $201 \mathrm{~Pa}$. Super. 70, 191 A.2d 725 (1963). But see Aqua Club Iiquor License Case, 202 Pa. Super. 192, 195 A.2d 802 (1963).

107 Significantly, the courts have deferred unquestioningly to the rulings of agencies of apparently equal or less experience. See, e.g., Pennsylvania State Athletic Comm'n v. Bratton, 177 Pa. Super. 598, 112 A.2d 422 (1955) (allocatur denied); Hogan v. Unemployment Compensation Bd. of Review, 169 Pa. Super. 554, 558-59 n.2, 83 A.2d 386, 389 n.2 (1951).

108 See Byse, Opportunity To Be Heard in License Issuance, 101 U. PA. L. REv. 57, 82 (1952) ; Schoenfeld, Administrative Discretion of the Pennsylvania Liquor Control Board in the Issuance of Licenses, 28 TEMP. L.Q. 161, 183 (1954).

109 See Chinds, Making Repeal Work 109 (1947); Jornt Committee Study 24-25. Compare Azarewicz Liquor License Case, 163 Pa. Super. 459, 463, 62 A.2d $78,80-81$ (1948) (dictum) (allocatur denied).

The Courts of Quarter Sessions of the various counties, of course are more sensitive to the desires and complaints of their constituents than they are to the general picture of the law over the entire state. For this reason, it is not only desirable but almost essential that there should be appeal from the findings of a local court to a state court if the local court has a right to set aside the findings of the Liquor Control Board.

Letter From Robert H. Jordan, Esquire, Former Attorney for the Pennsylvania Liquor Control Board, to the University of Pennsylvania Law Review, March 1964. 
1948 , one-third of the parties who were denied licenses appealed, and that two-thirds of these appellants were successful.110 Finally, there is the obvious duplication of effort demanded by full hearings before both the board and the quarter sessions courts.

Nevertheless, some authorities favor free exercise of discretion by the quarter sessions courts without regard to the board's previous disposal of the license application. At least one superior court judge ${ }^{111}$ prefers this complete review because of the quarter sessions courts' intimate knowledge of local conditions. Furthermore, to the extent that field examiners gather the facts necessary for board decisions, ${ }^{112}$ the board's findings of fact are arguably less reliable than those of experienced judges. ${ }^{113}$ The arguments against lower court discretion on appeal are therefore not so compelling that the appellate courts could justifiably hold without discussion that the 1949 amendment could not possibly have intended to overthrow the "abuse of discretion" standard.

The appellate courts, through either carelessness or attempted judicial statesmanship, might also have shown a reluctance to establish review standards for the liquor board that deviated from those of the state's Administrative Agency Law, ${ }^{114}$ which governs the bulk of state-wide agencies. ${ }^{115}$ That statute directs the reviewing court to affirm the agency decision unless it violates the appellant's constitutional rights, "is not in accordance with law," or "is not supported by substantial evidence." 116 This composite standard seems closely akin to "abuse of discretion." Although the liquor control board is governed by the Liquor Code's review provisions rather than by those of the Administrative Agency Law, ${ }^{117}$ cases decided under one statute have been cited in connection with the other. ${ }^{118}$ A tendency to assimilate the two may partially explain the failure to come to grips with the statutory de novo review language. ${ }^{119}$

110 See Byse, supra note 108, at 86.

111 See 425-429, Inc., Liquor License Case, $179 \mathrm{~Pa}$. Super. 235, 246, 116 A.2d 79, 85 (1955) (Ervin, J., dissenting) (allocatur denied).

112 See PA. Stat. AnN. tit 47, \$\$ 4-402, 4-464 (1952).

113 Cf. Byse, supra note 108 , at 84 .

114 Pa. Stat. AnN. tit. 71, $\S 1710.1-.51$ (1962), as amended, Pa. Stat. AnN. tit. 71, $\$ 1710.21, .51$ (Supp. 1964).

115 See PA. STAT. ANN. tit. 71, \$1710.51 (Supp. 1964).

116 PA. Stat. ANN. tit. 71, §1710.44 (1962); see Pennsylvania State Bd. of Medical Educ. \& Licensure v. Schireson, 360 Pa. 129, 61 A.2d 343 (1948). See generally Hanna, "Substantial Evidence" Under the Pemsylvania Administrative Agency Law, 20 PA. B.A.Q. 264 (1949).

117 Compare PA. Stat. AnN. tit. 71, §1710.44 (1962), with PA. Stat. Ann. tit. $47, \$ 4-464$ (1952).

118 See, e.g., Sable Unemployment Compensation Case, 197 Pa. Super. 177, 182, 177 A.2d 115, 118 (1962); Pennsylvania State Athletic Comm'n v. Bratton, $177 \mathrm{~Pa}$. Super. 598, 606, 112 A.2d 422, 425 (1955) (allocatur denied); cf. Appeal of Hotchkiss, 169 Pa. Super. 506, 83 A.2d 398 (1951) (citing Milk Control Comm'n case).

119 See Bell Appeal, $396 \mathrm{~Pa} .592,152$ A.2d 731 (1959), which was decided under the de novo review provision of the Policeman's Civil Service Act, PA. STAT. ANN. tit. 53, $\$ 23538$ (1957). The majority seemed to favor an "abuse of discretion" interpretation, $396 \mathrm{~Pa}$ at $613,152 \mathrm{~A} .2 \mathrm{~d}$ at 741, whereas Justices Musmanno, Bell, and $\mathrm{McBride}$, in two dissents, stated that the de novo provision vested absolute discretion in the reviewing court, $i d$. at $615,646,152 \mathrm{~A} .2 \mathrm{~d}$ at 742, 757. See also Baker Case, $409 \mathrm{~Pa}$. 143 , 185 A.2d 521 (1962) ("abuse of discretion" standard). 
Another force which may have impelled the appellate courts to keep absolute licensing discretion from the lower courts is a desire to avoid judicial encroachment on the legislature ${ }^{120}$ even though the exercise of administrative discretion by an agency might be a permissible delegation of a legislative function. ${ }^{121}$ The appellate court opinions in liquor licensing cases, however, have never referred to this potential restriction. Moreover, from 1887 to prohibition the courts alone exercised licensing authority bestowed under a very broad statutory standard directing them to hear testimony for and against the application and to assess the public need for the license and the fitness of the applicant. ${ }^{122}$

Although the Pennsylvania appellate courts have never drawn on the experience of other states in developing a standard of review under a statute providing for de novo appeal, such authority exists with supporting rationales. ${ }^{123}$ For example, the Texas courts have deliberately rejected a literal reading of the statutory "de novo" language ${ }^{124}$ and have adopted a rule requiring affirmance of the board unless its decision is not supported by "substantial evidence." 125 These opinions relied on considerations of efficiency and the appropriate role of the courts in the administrative process. ${ }^{126}$ Another Texas decision narrowed the scope of a de novo review to avoid an unconstitutional delegation of legislative power. ${ }^{127}$ Connecticut ${ }^{128}$ and New Mexico ${ }^{129}$ courts have also balked on constitutional grounds at according trial courts absolute discretion in liquor licensing cases. A contrary approach has been followed in Arizona, where the legislative command that the court on appeal "hear and determine the matter de novo" 130 has been applied literally. 131

Although the timing of the Pennsylvania amendment expanding de novo review to include "questions of fact, administrative discretion, and

120 PA. Const. art. $2, \S 1$ vests the legislative power in the Pennsylvania General Assembly. See Commonwealth v. Franklin, 172 Pa. Super. 152, 182-83, 92 A.2d 272, 287-88 (1952).

121 See Weinstein Liquor License Case, $159 \mathrm{~Pa}$. Super. 437, 48 A.2d 1 (1946) (allocatur denied); Marchines v. Pennsylvania Unemployment Compensation Bd. of Review, 148 Pa. Super. 1, 24 A.2d 691 (1942).

122 See, e.g., Cambria County Liquor License Case, 78 Pa. Super. 28, 29 (1921); Venango County Liquor License Case, $58 \mathrm{~Pa}$. Super. 277 (1914). See generally

Tate Liquor Iicense Case, $196 \mathrm{~Pa}$. Super. 193, 199-200, 173 A.2d 657, 660 (1961).

123 See generally Byse, stpra note 108, at 82-84.

124 Texas Penal Code art. 666-14 (1952).

125 See, e.g., Jones v. Marsh, 148 Tex. 362, 224 S.W.2d 198 (1949); Clark v. Liquor Control Bd., 357 S.W.2d 176 (Tex. Civ. App. 1962); Texas Liquor Control

Bd. v. Taylor, 338 S.W.2d 321 (Tex. Civ. App. 1960).

126 See Jones v. Marsh, 148 Tex. 362, 367, 224 S.W.2d 198, 201 (1949).

127 Bradley v. Liquor Control Bd., 108 S.W.2d 300 (Tex. Civ. App. 1937).

128 DeMond v. Liquor Control Comm'n, 129 Conn. 642, 30 A.2d 547 (1943).

The de novo review language is no longer in the Connecticut statute. See ConN.

Gen. Stat. Rev. \& 60 (1960), Cichon v. Liquor Control Comm'n, 14 Conn. Supp. 155

(Super. Ct. 1946).

129 See Yarbrough v. Montoya, 54 N.M. 91, 214 P.2d 769 (1950).

130 ARIz. Rev. Stat. ANn. \$4-210 (1956).

131 Lane v. Ferguson, 62 Ariz. 184, 156 P.2d 236 (1945) ; Duncan v. Mack, 59

Ariz. 36, 122 P.2d 215 (1942). 
such other matters as are involved" is a factor unique to the Pennsylvania courts, discussions by other state courts of the factors underlying their decision represent a more satisfactory judicial handling of the problem.

\section{Judicial Effectuation of Legislative Policy}

If the quarter sessions courts are to reverse the board only for abuses of discretion, they must confine their inquiries to possible misapplications of law or "manifestly unreasonable" decisions on the evidence presented to the court.132 One means of assessing the impact of "abuse of discretion" review upon the licensing process is to examine selected substantive issues in detail. Because of the presumed influence of appellate court opinions upon the lower tribunals and bar, particular attention will be given to the clarity and fidelity with which these opinions implement the legislative policy. To the extent that these policies are ignored, the courts cannot detect abuses of discretion with sufficient accuracy.

\section{A. The Distance Rules \\ 1. The 300 Foot Rule}

The Pennsylvania Liquor Code authorizes the board to refuse a license to premises within 300 feet of certain restrictive institutions: "[T] he board may, in its discretion, grant or refuse such new license or transfer if such place proposed to be licensed is within three hundered feet of any church, hospital, charitable institution, school or public playground . . . ."133 Similar provisions exist in many other states..$^{134}$

Clear policies-such as protection of children and avoidance of indignities to church property ${ }^{135}$ _ justify the board's discretionary power to deny a license where otherwise one would automatically issue. ${ }^{136}$ These policies should also cause a court in a close case to err on the side of denying a license. ${ }^{137}$ Appellate decisions have been responsive to these

132 E.g., Bierman Liquor License Case, 188 Pa. Super. 200, 206, 145 A.2d 876, 879 (1958); William E. Burrell I.B.P.O.E. of W. Liquor License Case, $172 \mathrm{~Pa}$ Super. 346, 350, 94 A.2d 110, 111 (1953); see Mielcuszny v. Rosol, 317 Pa. 91, 176 Atl. 236 (1934). This case, though not a liquor licensing case, has often been cited to determine abuses of discretion of the liquor control board.

133 PA. Stat. Ann. tit. 47, § 4-404 (Supp. 1964). (Emphasis added.)

134 In 1960 forty-one states limited liquor licenses near schools; thirty-eight states limited them near churches; and nineteen limited them near hospitals, playgrounds, or other institutions. JorNx ConanITTEE STUDY 37; see Annot., 59 A.L.R.2d 1439 (1958) (churches); Annot., 49 A.L.R.2d 1103 (1956) (schools).

135 See, e.g., Club Oasis, Inc., Liquor License Case, 200 Pa. Super. 439, 449, 188 A.2d 792, 797 (1963) ; Weiss Liquor License Case, 187 Pa. Super. 89, 142 A.2d 385 (1958).

136 See generally, Schoenfeld, supra note 108, at 175-79. The grant of discretion to the board in this area has been held constitutional. Clinton Management, Inc., Liquor License Case, $188 \mathrm{~Pa}$. Super. 8, 145 A.2d 873 (1958).

137 See, e.g., 425-429, Inc., Liquor Iicense Case, $179 \mathrm{~Pa}$. Super. 235, 241-42, 116 A.2d 79, 82 (1955) (allocatur denied); Rzasa's Liquor License Case, $179 \mathrm{~Pa}$. Super. 30, 34, 115 A.2d 797 (1955). 
considerations. Thus the rule has been established that the mere presence of a restrictive institution within 300 feet of the proposed liquor outlet is sufficient reason for the board to refuse a license, regardless of the array of other factors favoring the grant of the particular license. ${ }^{138}$ The board also has been allowed to deny a license despite the failure of the affected institutions to protest, ${ }^{139}$ and when the restrictive institution favors the license..$^{140}$ Also reflecting this stringent attitude, the 300-foot rule has been stretched to deny a license to a restaurant that cut three feet from a corner of its building to withdraw itself from the restricted area. ${ }^{141}$

In reviewing a license grant for abuse of discretion, the courts likewise permit the board a fairly wide latitude of decision and are as responsive to the appropriate considerations as they are in license denial cases. The board has been sustained in granting licenses within 300 feet of restrictive institutions upon finding factors such as a highly commercial neighborhood, an applicant of good reputation and character, an established restaurant to which the liquor business is only an auxiliary, the likelihood that patrons will not degrade the neighborhood, and that generally neither the neighborhood nor the restrictive institution would be harmed. ${ }^{142}$ However, the courts have made an exception to their general deference to board decisions. Although the Liquor Code requires a written opinion from the board only when it refuses a license, ${ }^{143}$ the reviewing courts, to promote the reasoned exercise of discretion by the board, and to insure against unwanted licenses in restricted areas, have creatively imposed on the board some responsibility to record their reasons for issuing a license. Accordingly, cases have held that if the board granted a license without filing an opinion, the quarter sessions court could then make its own findings and, if it arrived at a contrary result, reverse the board for an "abuse of discretion." 144 Only

138 Cialella Liquor License Case, $191 \mathrm{~Pa}$. Super. 526, 159 A.2d 64 (1960) (allocatur denied) ; 425-429, Inc., Liquor License Case, supra note 137, at 240,116 A.2d at 82; cf. Solomon Liquor License Case, $201 \mathrm{~Pa}$. Super. 82, 191 A.2d 681 (1963).

139 See, e.g., Haase Liquor License Case, 175 Pa. Super. 618, 621, 106 A.2d 865, 866 (1954) ; Her-Bell, Inc., Liquor License Case, 176 Pa. Super. 206, 210-11, 107 A.2d 572, 574 (1954) (dictum); cf. Club Oasis, Inc., Liquor License Case, $200 \mathrm{~Pa}$. Super. 439, 443-44, 188 A.2d 792, 794 (1963) (restrictive institution need not appeal).

140 425-429, Inc. Liquor License Case, 179 Pa. Super. 235, 241, 116 A.2d 79, 82 (1955) (dictum) (allocatur denied).

141 Haase Liquor License Case, 175 Pa. Super. 618, 106 A.2d 865 (1954) (alternative holding); accord, Rizzo Liquor License Case, 174 Pa. Super. 143, 100 A.2d 135 (1953). But see Appeal of Sons of Italy, 10 Fayette 77 (Ct. Quarter Sess. Fayette County, Pa., 1947).

142 See, e.g., Haase Liquor License Case, $184 \mathrm{~Pa}$. Super. 356, 359-60, 134 A.2d 682, 683-84 (1957); Appeal of First Presbyterian Church, 39 Washington 150 (Ct. Quarter Sess. Washington County, Pa., 1959); Zion Baptist Church v. Pennsylvania Liquor Control Bd., 66 Montgomery 80 (Ct. Quarter Sess. Montgomery County, Pa., 1950) ; 425-429, Inc., Liquor License Case, 179 Pa. Super. 235, 240, 116 A.2d 79 (1955) (dictum) (allocatur denied). But cf. Club Oasis Liquor License Case, 200 Pa. Super. 439, 188 A.2d 792 (1963).

143 Pa. Stat. Ann. tit. 47, § 4-464 (1952).

144 Cialella Liquor License Case, $191 \mathrm{~Pa}$. Super. 526, 159 A.2d 64 (1960) (allocatur denied); Hotchkiss Liquor License Case, 169 Pa. Super. 506, 83 A.2d 398 (1951) ; see Weiss Liquor License Case, 187 Pa. Super. 89, 142 A.2d 385 (1958); cf. Haase Liquor License Case, $184 \mathrm{~Pa}$. Super. 356, 134 A.2d 682 (1957). 
recently the superior court in Club Oasis, Inc., Liquor License Case, ${ }^{145}$ has proposed as statutory authority for this practice the Administrative Agency Law's requirement that a record be made including the reasons and findings for all adjudications. ${ }^{146}$ Although liquor board appeals are not subject to the Administrative Agency Law's standards, ${ }^{147}$ the court held that procedures before the board itself are governed by the Administrative Agency Law, ${ }^{148}$ at least to the extent that the board must file an opinion when an appeal is taken.

The courts' establishment of legal standards for the board through their handling of statutory terms has generally comported with the legislative objectives. For example, some lower courts had held that a "church" had to be a church building, and not merely a residence or other building in which the congregation regularly met. ${ }^{149}$ But in Her-Bell, Inc., Liquor License Case, ${ }^{150}$ the court, relying on state tax exemption cases, held that the regular use of any building for church services classifies it as a "church" under the Liquor Code.

The superior court has also given a broad construction to the term "school." Thus "school" has been held to include students' residences halls within the 300 foot area since the students had to walk to the school proper, which was more than 300 feet from the licensed premises. ${ }^{151}$ "School" has also been interpreted to include the definitely planned site of a school although the proposed license would expire before construction was completed, since under existing law the license would almost certainly be renewed. ${ }^{152}$ Significantly, the court drew on New York and Illinois cases to support its result.153 Finally, in its most recent effort in this area, the superior court has held that "school" included the property boundaries, even though the school buildings were further than 300 feet from the site of the proposed license. ${ }^{154}$ The school in this case was a resident institution and the surrounding land consisted in part of a farm used for the rehabilitation of the children. The court relied on a similar case involving a hospital, ${ }^{155}$ correctly perceiving that the purpose of the 300 foot rule does not depend solely on the location of the institution's buildings.

145200 Pa. Super. 439, 188 A.2d 792 (1963).

146 Pa. Stat. AnN. tit. 71, \$1710.34 (1962).

147 Compare PA. Star. AnN. tit. 71, \$1710.46 (1962), with PA. Stat. Ann. tit. 47, § 4-464 (1952).

148 See PA. Stat. ANN. tit. 47, \$2-206 (1952).

149 See, e.g., Appeal of Manheim Township Post No. 664 Am. Legion, 51 Lancaster 287 (Ct. Quarter Sess. Lancaster County, Pa., 1949) ; In re Rogowski, 32 Erie 269 (Ct. Quarter Sess. Erie County, Pa., 1949). But cf. Stehlik License, 67 Pa. D. \& C. 276 (Ct. Quarter Sess. Philadelphia County 1949).

$150176 \mathrm{~Pa}$. Super. 206, 107 A.2d 572 (1954). See generally Annot., 59 A.L.R.2d 1439 (1958).

151 Clinton Management, Inc., Liquor License Case, 188 Pa. Super. 8, 145 A.2d 873 (1958) (alternative holding).

152 DiRocco Liquor License Case, $167 \mathrm{~Pa}$. Super. 381, 74 A.2d 501 (1950). See generally Annot., 49 A.L.R.2d 1103 (1956).

153 DiRocco Liquor License Case, supra note 152 , at 385-86, 74 A.2d at 503-04.

604 (1964).

154 Jack's Delicatessen, Inc., Liquor License Case, 202 Pa. Super. 481, 198 A.2d

155 Lester Liquor License Case, 170 Pa. Super. 574, 87 A.2d 794 (1952). 
The handling of statutory terms has not, however, been without fault; occasionally, the courts have interpreted the term "charitable institution" even more broadly than was necessary to effectuate the statutory goals. Thus the superior court has held that the presence of a volunteer fire company may preclude issuance of a liquor license for premises within 300 feet. ${ }^{156}$ The court reached this curious result by relying on the common meanings of words and by citing cases defining fire companies as charities for the purposes of preventing dissipation of their funds. ${ }^{157}$ The court buttressed its conclusion by stressing the interference with the free movement of fire equipment that would be caused by the increased traffic attracted by the licensed premises. ${ }^{158}$ If this reason has any plausibility, it would seem more appropriately addressed to local zoning and traffic authorities than to the state liquor control board. Consideration of the other restrictive institutions listed in the statute-churches, hospitals, schools, and public playgrounds-suggests a legislative purpose that only those charities that would be particularly vulnerable to rowdy or indecent behavior should be permitted to block the licensing of a nearby premise.

\section{The 500 Foot Rule and the Effective Use of Allocatur}

Another "distance rule" in the Liquor Code is that the board shall refuse any application . . . if, in the board's opinion, such . . l license . . . would be detrimental to the welfare, health, peace and morals of the inhabitants of the neighborhood within a radius of five hundred feet of the place proposed to be licensed. ${ }^{\mathbf{1 5 9}}$

The birth of this legislation illustrates the value of judicious selection and decision of cases by the supreme court under its allocatur jurisdiction. Before the enactment of the above provision, the superior court, in Obradovich Liquor License Case, ${ }^{160}$ had affirmed both the board and the lower court in their denial of a license transfer. The applicant was fully qualified and the denial was based solely on the remonstrances of neighbors. The board and the courts had supported their result with a questionable interpretation of the statute that would have given the board discretion to deny a transfer even though an original issuance in the same circumstances would have been mandatory. ${ }^{161}$ The supreme court, ${ }^{162}$ having taken the case on allocatur, construed the statute to make both the transfer and

156 Subers Liquor. License Case, $173 \mathrm{~Pa}$. Super. 558, 98 A.2d 639 (1953) (allocatur denied); see Haase Liquor License Case, 175 Pa. Super. 618, 106 A.2d 865 (1954).

157 See also In re Appeal of Subers, 40 Delaware 22, 23 (Ct. Quarter Sess. Delaware County, Pa., 1952).

158 See Subers Liquor License Case, 173 Pa. Super. 558, 98 A.2d 639 (1953) (allocatur denied).

159 PA. Stat. Ann. tit. 47, §4-404 (Supp. 1964).

$160180 \mathrm{~Pa}$. Super. 383, 119 A.2d 839, rev'd, 386 Pa. 342, 126 A.2d 435 (1956).

161 See $180 \mathrm{~Pa}$. Super. at 391-96, 119 A.2d at 842-45 (dissenting opinion).

162 Obradovich Liquor License Case, 386 Pa. 342, 126 A.2d 435 (1956). 
the original issuance mandatory despite the protests of neighbors. Although this construction was compelled by both the language of the provisions involved and the broader statutory context, the court's opinion referred the matter to the legislature to fill the obvious gap in the board's discretionary powers. ${ }^{103}$

Probably recognizing the merit of the policy relied on by the board and the lower courts, the legislature amended the statute to allow the board to consider the deleterious effect of a license on the surrounding neighborhood.104 Against an attack that this grant of discretion was an unconstitutional delegation of legislative power, the court has subsequently held that the detrimental effect on the nearby inhabitants is merely a "fact" for the board alone to determine before the law is applied according to the statute. ${ }^{165}$

In a recent case the superior court sustained a board determination that the transfer of a license would be detrimental to the welfare, health, peace, and morals of the inhabitants within 500 feet of the proposed location. ${ }^{168}$ Since the quarter sessions court had also affirmed the board, the case was not a satisfactory vehicle for testing the extent to which the judiciary must defer to the board in its application of the 500 foot rule. Nevertheless, the court stressed the board's discretionary power, suggesting that board determinations will be accorded the judicial respect given to its 300 foot rule determinations.

\section{B. Clubs and Resorts}

1. Clubs

Since club licenses are subject to less stringent restrictions than are restaurant or hotel licenses, ${ }^{107}$ their unlimited issuance would undoubtedly result in organizations whose primary aim is the sale of liquor and also "one-man" clubs, which merely disguise an ordinary retail liquor operation by charging a small "membership" fee. ${ }^{188}$ In order to prevent these abuses, the Liquor Code contains a statutory definition of "club" that requires regular meetings, dues, continuity of existence, and a primary purpose other than the sale of liquor. ${ }^{169}$ A club may sell liquor only to its

163 Id. at 348,126 A.2d at $437-38$.

$164 \mathrm{~Pa}$. Laws 1959, 746; PA. Stat. ANN. tit. 47, \$4-404 (Supp. 1964); see Gismondi Liquor License Case, $199 \mathrm{~Pa}$ Super. 619, 186 A.2d 448 (1962); cf. 1621, Inc. v. Wilson, $402 \mathrm{~Pa}$. 94, 108, $166 \mathrm{~A} .2 \mathrm{~d}$ 271, 278 (1960) (picketing of taproom by neighbors not enjoined) ; Reid v. Brodsky, 397 Pa. 463, 156 A.2d 334 (1959) (enjoin taproom as a nuisance at neighbors' insistence).

165 Tate Liquor License Case, $196 \mathrm{~Pa}$. Super. 188, 193, 173 A.2d 657, 660 (1961).

160 Koehler's Bar, Inc., Liquor License Case, 204 Pa. Super. 25, 201 A.2d 306 (1964) (allocatur denied).

167 See Pa. Stat. Ann. tit. 47, §4-405 (1952), as amended, Pa. Stat. Ann. tit. 47, §4-405(d) (Supp. 1964) (license fees); PA. Star. ANn. tit. 47, §4-406 (Supp. 1964) (hours of operation).

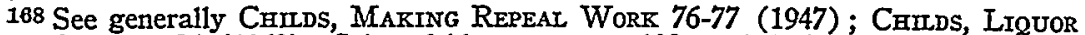
UNDER CONTROL 85 (1960); Schoenfeld, supra note 108, at 163-67.

169 See Pa. Stat. Ann. tit. 47, § 1-102 (1952). 
members. ${ }^{170}$ To prevent applicants from circumventing these standards by a merely formal compliance with the Liquor Code's requirements, "the board ... in the case of a club may, in its discretion, issue or refuse a license . . ." ${ }^{171}$ even though all other requirements are met and the license would be within the area quota.

The quota restrictions pertaining to club licenses further illuminate the legislative attitude toward this type of license. The board cannot issue a club license if the area quota is exceeded.172 This restriction indicates that the legislature wanted to limit the number of club licenses, even though the liquor sold under them would not be generally distributed to the community. A club license, however, is not counted against the quota to prevent issuance of a hotel or restaurant license. ${ }^{173}$ This provision seems to recognize that a club license is not the most effective way to fill a community's needs. Although most early lower court cases properly allowed the board wide discretion in its disposition of applications for a club license, ${ }^{174}$ the board has always been obligated to explain its denial of a seemingly valid application. ${ }^{175}$

\section{Resorts}

The quota law sets the maximum number of licenses in accordance with the community's population. Nevertheless, since the quota is measured by permanent population, an exception was enacted with regard to resort areas: "The board shall have the power to increase the number of licenses in any such municipality which in the opinion of the board is located within a resort area." 178 An exception to a quota, itself enacted to restrain the liquor business, invites strict construction. The language also suggests that the board's normal course of action might well be to deny resort licenses, since it was given only the "power," not the duty, to exceed the quota. Moreover, the phrasing seems to commit to the board alone the determination whether a particular area is a resort for purposes of disregarding the quota limits.

The courts have explained the guiding policy of the "resort" exception to be that licenses should be equitably distributed to accommodate

170 Carver Community Center Liquor License Case, 200 Pa. Super. 517, 522, 189 A.2d 914, 916 (1963).

171 Pa. Stat. ANn. tit. 47, §4-404 (Supp. 1964). (Emphasis added.)

172 See Pa. Stat. AnN. tit. 47, §4-461 (a) (Supp. 1964).

173 Ibid.

174 See, e.g., Log Cabin Rod \& Gun Club License, 66 Pa. D. \& C. 188 (Ct. Quarter Sess. Lebanon County 1948); Willow Grove Veterans Home Association's Application, 61 Montgomery 223 (Ct. Quarter Sess. Montgomery County, Pa., 1945); Iin re Appeal of San Marco Soc'y, 35 Berks 239 (Ct. Quarter Sess. Berks County, Pa., 1943). But see Appeal of Moxie Club. 50 Lackawanna 249 (Ct. Quarter Sess. Lackawanna County, Pa., 1949) ; In re Geiger-Zimmerman VFW Home, Inc., Appeal,

41 Berks 177 (Ct. Quarter Sess. Berks County, Pa., 1949).

175 See William E. Burrell I.B.P.O.E. of W. Liquor License Case, $172 \mathrm{~Pa}$. Super. 346, 94 A.2d 110 (1953).

176 PA. Stat. Ann. tit. 47, §4-461(b) (1952). (Emphasis added.) 
transients in areas with large seasonal population increases. ${ }^{177}$ While such an explanation of the legislative intent is surely within the court's province of stating the "law" that controls the board's deliberations, the task of sifting and weighing the facts bearing on whether any given area is a "resort" should remain with the board. If an "abuse of discretion" standard is to govern court review, a board determination of "resort" status that is reasonable in light of the legislative goals should not be reconsidered by the courts. ${ }^{178}$

In addition, even if an area is found to be a resort, the license should not issue unless it is needed to satisfy an unusual seasonal demand. In accommodating these needs, the board, and the reviewing courts, should assess the requirements of the locale and the usefulness of the type of facility proposed to be licensed instead of automatically granting additional licenses in a given resort area..$^{179}$ The situation seems to be a particularly apt one for the courts to defer somewhat to the expert agency's interpretation and implementation of its regulatory statute..$^{180}$

\section{Clubs in Resort Areas}

Since the only purpose for the resort exception is to accommodate a seasonal influx of transients, private clubs, which may serve only members,

177 See Bierman Liquor License Case, 188 Pa. Super. 200, 205, 145 A.2d 876, 879 (1958).

178 I can specifically recall one case where a resort area license was granted to an applicant whose place of business was within a few blocks of an automobile junkyard, a quarry, huge culm piles and no recreational facilities whatsoever. The Board in preparing its case felt that the court could even take judicial notice that the area was not a resort area but notwithstanding that used photographs and oral testimony to prove the nature of the place. The court then made its decision on the basis of oral testimony and as the factfinding agency had the right to make different findings of fact than the Board made, did find that there were recreational facilities as a matter of law. The record made by the Board was inadequate for an appeal and the Board had to change its entire program of licensing.

Letter From Robert H. Jordan, Esquire, Former Attorney for the Pennsylvania Liquor Control Board, to the University of Pennsylvania Law Reviev, March, 1964.

See Andes Grove Rod \& Gun Club Liquor License Case, $201 \mathrm{~Pa}$. Super. 21, 25, 190 A.2d 355, 357 (1963); Willowbrook Country Club, Inc., Liquor License Case, $409 \mathrm{~Pa} .370,376,187$ A.2d 154, 157 (1962) (dissenting opinion); cf. Symons v. National Elec. Prods., Inc., $30 \mathrm{~Pa}$ D. \& C.2d 112, 121-22 (C.P. Beaver County 1962), aff'd per curiam, $201 \mathrm{~Pa}$. Super. 27, $192 \mathrm{~A} .2 \mathrm{~d} 897$ (1963), aff'd, $414 \mathrm{~Pa} .505$, 200 A.2d 871 (1964). See also Kreiser Liquor License Case, $188 \mathrm{~Pa}$. Super. 206, 145 A.2d 880 (1958); Bierman Liquor License Case, 188 Pa. Super. 200, 145 A.2d 876 (1958); Blue Mountain Country Club License, 9 Pa. D. \& C.2d 37 (C.P. Perry County 1956); Lance License, 83 Pa. D. \& C. 150 (Ct. Quarter Sess. Susquehanna County 1952). But see Minnichbach License, 24 Pa. D. \& C.2d 749 (Ct. Quarter Sess. Pike County 1961) ; Appeal of Elkview Country Club, 56 Lackawanna 32 (Ct. Quarter Sess. Lackawanna County, Pa., 1954).

179 See William Penn Sportsmen's Ass'n Liquor License Case, $196 \mathrm{~Pa}$. Super. 519, 523, 175 A.2d 908, 910 (1961); Minnichbach License, 24 D. \& C.2d 749 (Ct. Quarter Sess. Pike County 1961); Greene-Dreher Legion Home License, $69 \mathrm{~Pa}$. D. \& C. 425 (Ct. Quarter Sess. Pike County 1949). But see In re Appeal of Panco, 42 Luzerne 58 ( $\mathrm{C}_{\mathrm{t}}$ Quarter Sess. Luzerne County, Pa., 1951) (quarter sessions court granted license although quota of three was exceeded by eighteen).

180 See generally Davis, Administrative Law Text $\$ 30.09-.11$ (1959). 
are the least appropriate outlets to fill the need. ${ }^{181}$ An applicant for a club license in excess of quota in an area alleged to be a resort thus should have to overcome three statutory hurdles-the board's general discretion to deny a club license and its possible determinations either that the license is not needed in the area or that the area is not even a resort. The courts should be correspondingly reluctant to overturn the board's denial of a license. Since an additional club license in a resort may have affirmative value in alleviating a seasonal strain on local facilities, the presumption against its issuance may not be as strong as that present in the case of premises within 300 feet of a restrictive institution. ${ }^{182}$ But certainly substantial weight should be given to the board's decision against a resort club license.

However, despite the obstacles presented by the combined statutory barriers against "club" and "resort area" licenses, the courts have been unusually generous to applicants for club licenses in resort areas. ${ }^{183}$ The reason is that in reviewing these applications, the courts have frequently lost sight of the judicially defined goal of the legislation-the equitable distribution of licenses to accommodate great seasonal increases in population. Furthermore, in this area, even the appellate courts often appear to give little weight to the board's decisions or to the board's broader role in administering the Liquor Code.

The stress on seasonal population shifts in defining a "resort" should make irrelevant the nature of the "resort's" recreational facilities, provided the inflow of visitors is substantial and predictable. Thus, the fact that the only attractions are picnicking and clambakes, or hunting and fishing, should not prevent an area from being a "resort" if enough vacationers regularly visit it. Yet some opinions have given weight to the nature of the recreational facilities. ${ }^{184}$ Conversely, even when facilities of "resort-quality" have been only under construction, the courts have ignored the possibility that their incomplete stage of development may not yet warrant the grant of additional licenses. ${ }^{185}$ An appellate court has also

181 See Blue Mountain Country Club License, 9 Pa. D. \& C.2d 37, 45-46 (C.P. Perry County 1956); cf. Greene-Dreher Legion Home License, 75 Pa. D. \& C. 84 (Ct. Quarter Sess. Pike County 1951). But see Riegelsville Legion Home Liquor License Case, 86 Pa. D. \& C. 309 (Ct. Quarter Sess. Bucks County 1953).

182 See 425-429, Inc., Liquor License Case, $179 \mathrm{~Pa}$. Super. 235, 116 A.2d 79 (1955) (allocatur denied); see note 138 supra and accompanying text.

183 See, e.g., Wildwood Golf Club Liquor License Case, $199 \mathrm{~Pa}$. Super. 353, 185 A.2d 649 (1962) (allocatur denied); Willowbrook Country Club, Inc. Liquor License Case, 198 Pa. Super, 242, 181 A.2d 698, aff'd, 409 Pa. 370, 187 A.2d 154 (1962); Mannitto Haven Liquor License Case, 196 Pa. Super. 524, 175 A.2d 911 (1961); William Penn Sportsmen's Ass'n Liquor License Case, 196 Pa. Super. 519, 175 A.2d 908 (1961) ; Riegelsville Legion Home Liquor License Case, 86 Pa. D. \& C. 309 (Ct. Quarter Sess. Bucks County 1953).

184 See Andes Grove Rod \& Gun Club Liquor License Case, 201 Pa. Super. 21, 190 A.2d 355, 356 (1963) (allocatur denied); Appeal of Sunseri, 22 Cambria 96 (Ct. Quarter Sess. Cambria County, Pa. 1959); Steigerwalt License, 14 Pa. D. \& C.2d 614 (Ct. Quarter Sess. Schuylkill County 1958).

185 See Willowbrook Country Club, Inc. Liquor License Case, $198 \mathrm{~Pa}$. Super. 242, 181 A.2d 698, aff'd, 409 Pa. 370, 187 A.2d 154 (1962); William Penn Sportsmen's Ass'n Liquor License Case, 196 Pa. Super. 519, 175 A.2d 908 (1961). But cf. Appeal of Sunseri, 22 Cambria 96, 102-03 (Ct. Quarter Sess. Cambria County, Pa., 1959). 
held that an area will not be deemed a resort if the sole attraction derives from the applicant club's own facilities and activities. ${ }^{186}$ The merit of this position is undeniable if the club's membership is static and is drawn only from the neighborhood of the club, but the court denied resort status to a club with 331 family memberships that attracted about 25,000 guests during the summer months. ${ }^{187}$ The grounds for denial were that the surrounding area was predominantly residential, and not a resort area.

The viewpoint of the court may have derived from the many cases granting licenses to clubs because they adjoined other resort facilities. ${ }^{188}$ But these decisions seem likewise to pervert the policy of the resort exception, for they concentrate only on the resort characteristics of the surrounding area while largely disregarding the fact that a club license is often the least efficient way to satisfy increased seasonal demand with a minimum of licenses in excess of quota. Once an area is found to qualify for additional liquor licenses under the quota law's resort exception, policy judgments regarding the number and type of additional licenses must be made upon consideration of the seasonal increase in population and the capacity of nearby facilities. ${ }^{189}$ These factors make each case unique, and thus seem even less appropriate for redetermination by the courts than is an area's "resort" classification. ${ }^{190}$ Yet, the reviewing courts have repeatedly reversed the board on these issues. ${ }^{101}$ The board has been consistently unable to prevail with its contention that a club license is the least likely to satisfy the needs of the area's seasonal transient population, since the clubs may serve only members and their guests. ${ }^{192}$ The courts generally have countered by pointing to the large numbers of vacationers attracted to surrounding areas, without recognizing the essential irrelevance of this circumstance since the club will probably never serve them. One opinion expressed the fear that affirming the board on this issue would

186 See Riviera Country Club Liquor License Case, 201 Pa. Super. 70, 191 A.2d 725 (1963); Blue Mountain Country Club License, 9 Pa. D. \& C.2d 37 (C.P. Perry County 1956) (dictum).

187 Riviera Country Club Liquor License Case, $201 \mathrm{~Pa}$. Super. 70, 191 A.2d 725 (1963). But cf. Willowbrook Country Club, Inc. Liquor License Case, $198 \mathrm{~Pa}$. Super. 242,181 A.2d 698, aff'd, $409 \mathrm{~Pa} .370,187$ A.2d 154 (1962) (area with 5,000 to 6,000 yearly visitors entitled to resort status).

188 See, e.g., Willowbrook Country Club, Inc. Liquor License Case, supra note 187; William Penn Sportsmen's Ass'n Liquor License Case, $196 \mathrm{~Pa}$. Super. 519, $175^{\circ}$ A.2d 908 (1961).

189 See, e.g., Willowbrook Country Club, Inc. Liquor License Case, $409 \mathrm{~Pa} .370$, 374-75, 187 A.2d 154 (1962); Appeal of Elkview Country Club, 56 Lackawanna 32 (Ct. Quarter Sess. Lackawanna County, Pa., 1954).

190 Cf. Symons v. National Elec. Prods., Inc., $30 \mathrm{~Pa}$. D. \& C.2d 112 (C.P. Beaver County 1962), aff'd per curiam, $201 \mathrm{~Pa}$. Super. 27, 172 A.2d 897 (1963), aff'd, 414 $\mathrm{Pa} .505,200$ A.2d 871 (1964) (existence of disability under Workmen's Compensation Act is a question of fact for the board and is not reviewable in the absence of a clear abuse of discretion). See generally Davis, Administrative LAw Text $\$ 30.11$ (1959).

101 See authorities cited note 183 supra.

192 See, e.g., Willowbrook Country Club, Inc. Liquor License Case, $409 \mathrm{~Pa} .370$, 374, 187 A.2d 154, 156 (1962); William Penn Sportsmen's Ass'n Liquor License Case, $196 \mathrm{~Pa}$. Super. 519, 522-23, 175 A.2d 908, 910 (1961). But see Greene-Dreher Legion Home License, 75 Pa. D. \& C. 84, 86 (Ct. Quarter Sess. Pike County 1951). 
forever preclude club licenses in resort areas. ${ }^{193}$ However, the courts could easily distinguish for favorable treatment those situations in which the visitors who account for the increase in the resort area's population are themselves the members of the club. ${ }^{191}$

Finally, the decisions are plagued by recurring considerations that border on the irrelevant and that consequently can only serve to mislead attorneys and judges who refer to them in future cases. For example, substantial investment in club facilities should not weigh in favor of granting a club license, since the club members should have been aware of the obstacles to getting a liquor license when they initiated the undertaking. ${ }^{195}$ Similarly, the fact that club members feel ill at ease in other local establishments, ${ }^{196}$ while perhaps relevant to the issuance of a club license, would not seem to justify granting them a club license in excess of quota. Finally, laborious descriptions of the history of the region ${ }^{197}$ and the nature of nearby recreational facilities ${ }^{198}$ seem unnecesesary except as they bear on the magnitude of the seasonal population increase.

The Pennsylvania Supreme Court did little to effectuate the statutory policies when it decided Willowbrook Country Club Liquor License Case ${ }^{199}$ on allocatur. In ruling that the area in question was a "resort," the court noted:

Under the undisputed facts, there is an unusual and great influx of people into this particular area during certain seasons of the year. It is quite obvious to us that the character and number of the usual licenses could not possibly meet the existing need. ${ }^{200}$

The "unusual and great influx of people" was in fact only 5,000 to 6,000 over the course of the season, and the quota for the area was already exceeded by three. ${ }^{201}$ Hence, under the existing statutory formula of one

193 Wildwood Golf Club Liquor License Case, $199 \mathrm{~Pa}$. Super. 353, 360, 185 A.2d 649, 653 (1962) (allocatur denied).

194 See, e.g., Mannitto Haven Liquor License Case, 196 Pa. Super. 524, 175 A.2d 911 (1961); William Penn Sportsmen's Ass'n Liquor License Case, 196 Pa. Super. 519, 175 A.2d 908 (1961); Appeal of Elkview Country Club, 56 Lackawanna 32 (Ct. Quarter Sess. Lackawanna County, Pa., 1954).

195 See, e.g., Riviera Country Club Liquor License Case, $201 \mathrm{~Pa}$. Super. 70, 191 A.2d 725 (1963); Vittorio Emanuele III Club Case, 22 Westmoreland 213, 218 (Ct. Quarter Sess. Westmoreland County, Pa., 1939); cf. Reid v. Brodsky, $397 \mathrm{~Pa}$. 463, 466 n.3, 156 A.2d 334, 337 n.3 (1959). But cf. Willowbrook Country Club, Inc. Liquor License Case, 198 Pa. Super. 242, 181 A.2d 698, aff'd, 409 Pa. 370, 187 A.2d 154 (1962).

106 See Aqua Club Liquor License Case, 202 Pa. Super. 192, 195, 195 A.2d 802, 804 (1963) (allocatur denied) ; Riegelsville Legion Home Liquor License Case, 86

Pa. D. \& C. 309, 318 (Ct. Quarter Sess. Bucks County 1953).

197 See Wildwood Golf Club Iiquor License Case, 199 Pa. Super. 353, 185 A.2d

649 (1962) (allocatur denied).

198 See, e.g., Willowbrook Country Club, Inc. Liquor License Case, $198 \mathrm{~Pa}$. Super.

242, 181 A.2d 698, aff'd, 409 Pa. 370, 187 A.2d 154 (1962); Windber Country Club

License, $31 \mathrm{~Pa}$. D. \& C.2d 190 (Ct. Quarter Sess. Cambria County 1963).

199409 Pa. 370, 187 A.2d 154 (1962).

$200 \mathrm{Id}$. at $373,187 \mathrm{~A} .2 \mathrm{~d}$ at 155.

$201198 \mathrm{~Pa}$. Super. at 243-44, 181 A.2d at 699. 
license for each 1500 inhabitants, ${ }^{202}$ it is hardly "quite obvious" that the existing facilities were inadequate. The supreme court thus followed the lower courts' unsatisfactory practice of not demonstrating how the facts of the case bring it within the policy of the properly stated general rule. The court did not acknowledge the board's contention before the superior court ${ }^{203}$ that the area was not yet sufficiently developed to be classified as a resort.

In Willowbrook the board had argued that a catering club license ${ }^{204}$ is not the best vehicle for satisfying a resort area's increased demand.205 The supreme court answered by quoting an oft-repeated ${ }^{208}$ dictum that anomalously seems to facilitate the granting of club licenses in resort areas:

The term "actual necessity" in determining the need for a liquor license [in a resort area] will be given a broad construction so as to mean substantial need in relation to the pleasure, convenience and general welfare of the persons who make use of the facility. ${ }^{207}$

In this instance the court at least referred to the relevant circumstance that all nearby taverns were too small to accommodate Willowbrook's membership. ${ }^{208}$ However, it did not mention that the club's membership of $465^{209}$ constituted less than ten percent of the 5,000 to 6,000 yearly inflow. By stressing the needs of the club members, rather than that of the resort area, the court seems to have thwarted both the statutory policy and the board's efforts to issue only those licenses best calculated to satisfy the demand which initially warranted exceeding the quota.

\section{ConCLUSION}

The Pennsylvania appellate courts' review of liquor board decisions has been of uneven quality. The courts have generally limited quarter sessions courts' scope of review more than might have been necessary under the controlling statute, although at times-particularly in the instance of resort clubs-they have delved into more detail than their professed "abuse of discretion" standard should have permitted. The tendency to limit review may represent an attempt to modify the statutory pattern

202 Pa. Stat. Ans. tit. 47, §4-461 (a) (Supp. 1964). officer).

203 See $198 \mathrm{~Pa}$. Super. at 246, $181 \mathrm{~A} .2 \mathrm{~d}$ at 700 (testimony of board enforcement

$201 \mathrm{~A}$ catering club, in addition to serving members, may serve groups of nonmembers that use the facilities of the club by prior arrangement made at least twentyfour hours in advance. PENNSYlvania Lrouor Control Board Regulations § 113.11 (1965).

205409 Pa. at 374, 187 A.2d at 156.

200 See, e.g., Mannitto Haven Liquor License Case, 196 Pa. Super. 524, 175 A.2d 911 (1961); William Penn Sportsmen's Ass'n Liquor License Case, $196 \mathrm{~Pa}$. Super. 519, 175 A.2d 908 (1961).

$207409 \mathrm{~Pa}$. at $375,187 \mathrm{~A} .2 \mathrm{~d}$ at 158.

208 Ibid.

209 See $198 \mathrm{~Pa}$. Super. at 245, $181 \mathrm{~A} .2 \mathrm{~d}$ at 700. 
allowing the quarter sessions courts of each county to redetermine licensing questions, a practice which carries the risk of disregarding the viewpoints and prior decisions of the board and of other lower courts. The frequent lack of attention to scope of review issues and other matters of broad policy may possibly be attributed to lax presentation of counsel.

Undoubtedly, the appellate courts reach reasonable results in the great majority of cases. Whether this is because of or in spite of their prior decisions is less clear. Liquor licensing opinions have too often been sprinkled with misleading dicta, improper citation of authority, misapplication of statutory policies, and disregard of controlling statutory language. The Pennsylvania Supreme Court, whether because of oversight or press of business, has ventured into the area of liquor licensing too infrequently, and then with only mixed results that do not represent the most effective use of its discretionary jurisdiction. Appellate opinions in this area need more care and analysis before they can achieve maximum guidance for the board, the lower courts, and the bar while remaining within the confines of appropriate judicial process.

Richard A. Jacoby $\dagger$

† LL.B. 1964, University of Pennsylvania. Note Editor, Volume 112. 